\title{
Teacher Attitudes towards ICT in the Context of Inclusive Education
}

\author{
José Maㅡ Fernández-Batanero \\ University of Sevilla \\ C/Pirotecnia s/n \\ 41010 Sevilla \\ +34616095357 \\ batanero@us.es
}

\author{
$M^{a}$ Jesús Colmenero Ruiz \\ University of Jaén \\ campus las lagunillas \\ +34953211803 \\ mjruiz@ujaen.es
}

\begin{abstract}
This communication provides the results of a study whose purpose was to determine how a teacher will use and integrate the 'Information and Communication Technologies' (ICT) in inclusive classrooms. This will also identify the factors that promote good educational practices supported by ICT. Towards this we prepared a case study of multiple cases. The questionnaire and group discussion are the techniques that are used for collecting required information. The result shows that teachers in general have a positive attitude towards ICT, especially the male teachers with greater possibilities of interaction with ICT. This will also promote inclusive and cultures policies between networks of schools and it is presented as an important factor in developing good educational practice with the support of ICT.
\end{abstract}

\section{Categories and Subject Descriptors}

- Project and people management $\rightarrow$ Computer and information systems training

- User characteristics $\rightarrow$ People with disabilities

\section{Keywords}

Teaching attitudes; information and communication technologies; inclusive education; good educational practice; educational innovation; secondary education; education.

\section{INTRODUCTION}

Inclusion and Intercultural configuration is an area of greater scientific interest at present. As an object of study and a category of analysis, educational inclusion has experienced a steady increase in the number and variety of research in the last decade.

Permission to make digital or hard copies of all or part of this work for personal or classroom use is granted without fee provided that copies are not made or distributed for profit or commercial advantage and that copies bear this notice and the full citation on the first page. Copyrights for components of this work owned by others than ACM must be honored. Abstracting with credit is permitted. To copy otherwise, or republish, to post on servers or to redistribute to lists, requires prior specific permission and/or a fee. Request permissions from Permissions@acm.org. TEEM '15, October 07-09, 2015, Porto, Portugal (C) 2015 ACM. ISBN 978-1-4503-3442-6/15/10...\$15.00 DOI: http://dx.doi.org/10.1145/2808580.2808598
Today, we know the development of inclusive education requires constant analysis of educational practices and processes of school change. In this sense, a considerable number of authors agreed to consider teachers as a key piece to satisfy the student needs in order to promote quality education for "all" students. So, the professor and his attitude to certain agents or elements influencing in teaching-learning, stand as a key factor to consider in education. Along these lines, there have been many works that are made in relation to attitudes, but still unsure what teacher attitudes to information technology and communication (ICT) related to attention to diversity can be used as a powerful tool to promote inclusion and multiculturalism. ICT is critical to the development of quality education in the context of attention to diversity. However, in the Spanish context, the way for the integration of ICT in education has not been easy and even today, its full potential has not been reached, which the pedagogical thought has not kept pace with technological advances similarly. Advances in inclusive education in developed countries are very slow. A deeply transformation of the educational actions is highly needed in today's world.

It is in this transformation where the attitude of teachers, compared to the use of ICT is a key aspect joined to other aspects as the skills and resources available to carry out this integration. However, there are still many education professionals who have not developed a favorable attitude to ICT as part of the attention to diversity. This may be one of the reasons for not to use them in the classroom, leading to a lack of use of the benefits that these technologies can bring both into their work and the student learning (Hinojo \& Fernández Granada, 2002).

Thus, most studies where it comes to getting the degree of implementation of ICT in schools include a section referring to the attitudes of teachers (Cabero, 1991; Mooij, 2004; Canales \& Marqués, 2007; Tejedor, García-Valcarcel \& Prada, 2009, Sáez López 2010; Área, 2008, 2010a, 2010b; Fernández-Batanero \& Bermejo, 2012; Luz Colorado \& Edel, 2012; Fernández Batanero $\&$ Torres, 2015) because they are a good predictor of the implementation, integration and use of ICT in education.

The relevance and motivation of this small contribution lies in the fact that analyzing the integration of ICT in education must consider not only the rational arguments but also the emotions behind them, emotions come to increase the complexity to this integration process. In other words, the attitudinal dimension of teachers is a key element for the pedagogical innovation and the development of good educational practices in diverse contexts (Cavas \& otros, 2009; Sipilä, 2010).

To admit that we are equal neither in the biological thing nor in the sociocultural thing minimizes the risk of social exclusion for 
ethnic, religious and linguistic factors, between others. In this line, we verify that the technologies facilitate the respect for the diversity since they allow that every person should accede to the information from his own characteristics and conditions (Zarceño \& Andreu, 2015).

The teachers compromised with the incorporation chase that all the pupils have attainable goals of learning and, also, that the planning and the educational evaluation go beyond the academic thing, to centre on the interpersonal relations, the emotional wellbeing, the social incorporation and other dimensions of the quality of life of the student body (Verdugo \& Rodríguez, 2012). In addition, the discentes demonstrate a positive attitude, even openly enthusiast, towards the employment of the ICT, for what the ICT might help to create an environment of ideal learning, opened to all, firmly inclusively (Cerrillo, Esteban \& Paredes, 2014).

\subsection{Establishment of the problem}

The most critical factor for inclusive education is the teacher staff. There are still many teachers of Secondary Education (ESO) who are not skilled enough to face the profound transformation that requires the educational system under the challenge of this model. So, considering the need for teacher staff to incorporate ICT for development of good educational practices and the role of attitudes in the success of integration programs for these technological teaching tools in this study raised the following research questions. Which attitudes have teachers of inclusive classrooms to ICT? Which factors favour the development of good educational practices in teaching-learning processes with ICT support?

\section{METHOD}

\subsection{Objetive}

The overall purpose of the study was to describe the attitudes of the teachers towards ICT, carrying out professional work in the inclusive classrooms and to identify those factors that favour the development of good educational practices of teaching-learning processes with ICT support.

\subsection{Design}

Regarding the type of design, it is a multiple case study, namely two schools, public, Secondary Education (ESO) in Seville (Spain). The selection of cases was made intentionally considering the criterion of being inclusion-oriented schools and being cataloged by the Andalusian Educational Administration as "good practice" school. The focus of data collection and analysis has been defined as mixed, in which qualitative and quantitative techniques are integrated. These two techniques (questionnaire and group discussion) are used to collect necessary information.

\subsection{General context}

The first school has approximately hundreds of pupils, $18 \%$ are from foreign origin (Morocco, Sahara, Romania, China, Bolivia and Colombia). The student body is characterized by a high percentage of shortage of motivation, deficit of instrumental subjects, poor academic performance, disruptive and conflictive behaviors, and family breakdown. There are in total 45 teachers in this school. The second school welcomes 420 students from 10 different nationalities. The total of teachers during the 2010/2011 academic year was 27. The school has a large number of students diagnosed with Attention Deficit Hyperactivity Disorder (ADHD), learning disorders and a student with Oppositional Defiant Behaviour.

In total 63 teachers participated in the study (38 women and 25 men) with an average of 18 years teaching experience. Regarding their stability valued from the administrative status of teachers, it shows that most of them are civil servants in a percentage of $84.4 \%$, in addition to $12.5 \%$ of interim staff and $3.1 \%$ of workforce, so the continuity of jobs in these schools are quite stable.

\subsection{The questionnaire «Attitudes towards ICT»}

A list of items were raised to measure the teachers attitude towards the usage of ICT, with answers in a Likert scale ranging from Strongly Agree (5) to Strongly Disagree (1). A factor analysis with oblique rotation method was performed to determine construct validity. $\mathrm{KMO}$ in .88 gives a proper adequacy to the model and Bartlett's test of sphericity that revealed to be significant $(\mathrm{p}=0.000)$. Two factors were extracted to explain $49.9 \%$ of the variance of the construct. In table 1 both of the factors and its corresponding items are shown.

Table 1. Specifications of questionnaire

\begin{tabular}{|l|l|l|}
\hline \multicolumn{1}{|c|}{ Factor } & \multicolumn{1}{|c|}{ Definition } & \multicolumn{1}{c|}{ Indicators } \\
\hline $\begin{array}{l}\text { Supporting } \\
\text { teacher } \\
\text { professional } \\
\text { development }\end{array}$ & $\begin{array}{l}\text { Rating on aid offered by } \\
\text { and in the teaching- }\end{array}$ & $\begin{array}{l}1,2,3,4,5,6,7,8,9 \\
\text { learning process }\end{array}$ \\
\hline $\begin{array}{l}\text { Ability and } \\
\text { availability }\end{array}$ & $\begin{array}{l}\text { Rating regarding the } \\
\text { access and management of }\end{array}$ & $22,16,12,18,19$, \\
& ICT & \\
\hline
\end{tabular}

Reliability was estimated using Cronbach's alpha by factor and overall instrument, obtaining a good internal consistency in all the cases: support the educational and professional development (.80); ability and availability (.81) and Global (.87).

SPSS 17 and descriptive and other inferential statistical programs were used to analyze the data.

\section{RESULTS}

\subsection{The questionnaire}

The data obtained shows that at global level also factors studied, teachers revealed a positive attitude towards ICT: Support in professional and educational development (X: 4.39); ability and availability (X: 3.80) and overall (X: 4.05).

Student-t test was used for related samples to establish whether there were significant differences in scores of different factors. The result confirms that there are significant differences in the scores of the factors, the greater the support for the factor in professional and educational development, which implies that the attitudes of teachers are more positive in this aspect.

If we pay attention to teachers attitudes towards ICT, the relation of these towards "gender" variable, a T-Student test was accomplished for independent samples, in order to establish whether there were statistically significant differences between factor scores and global instrument according to these variables. The result shows that scores of men are significantly higher in the global (X: 3.86) and Ability and availability (X: 3.92), compared to women. 
Implying that their attitudes in general are more positive especially with regard to perceived ability and availability in use of ICT (Table 2).

Table 2. Gender comparisons

\begin{tabular}{|l|l|c|c|c|}
\hline \multicolumn{1}{|c|}{ Factors } & Gender & $\boldsymbol{X}$ & $\boldsymbol{T}$ & $\boldsymbol{p}$ \\
\hline $\begin{array}{l}\text { Supporting teacher } \\
\text { professional } \\
\text { development }\end{array}$ & $\mathrm{F}$ & 4.34 & -1.034 & .301 \\
\hline & $\mathrm{M}$ & 4.52 & & \\
\hline Ability and availability & $\mathrm{F}$ & 3.61 & -2.290 & .024 \\
\hline & $M$ & 3.92 & & \\
\hline Global & $\mathrm{F}$ & 3.54 & -2.600 & .045 \\
\hline & $M$ & 3.86 & & \\
\hline$* p \leq .05$ & \multicolumn{5}{|l}{} \\
\hline
\end{tabular}

Regarding the variable "Age", two groups of teachers were established, first group included teachers aged from 20 to 40, and the second aged from 41 to 60 . As with the gender variable Student-t Test for independent samples was used, no significant differences found in the scores for both the groups.

To study the interaction between the teacher and ICT two indicators were considered, as both can facilitate access to use of technologies. On the one hand, the fact that teachers have computer at home and the second point is that these same teachers would impart the final years of compulsory secondary education. Regarding the former, although a large majority of teachers have a computer at home (95\%), the scores of the instrument according to whether or not the teachers had computers at home, using a Student $t$ test for independent samples were compared. The result shows that at the global level and at "availability and availability", scores of teachers having computer at home are significantly higher than those not having one; this implies that those having computers at home have more positive attitudes towards ICT versus those not having one.

According to the course they teach in the classes, teachers were divided into two groups. Those who develop their teaching in the first cycle of compulsory secondary education (1st and 2 nd) and those in the second cycle of compulsory secondary education (3rd and 4th).

\subsection{Discussion Groups}

The discourse analysis confirms and extends the results obtained in other studies (Canales \& Marqués, 2007). In this regard, a number of factors of good educational practices with ICT support were removed and they were grouped into two main sections (Table 3):

Table 3. Factors favoring good educational practices Teachers and Teacher Professional Development

Stimulate knowledge acquisition.

Enhance the socio-affective aspects of students.

Promote communication with students.

Designing and planning tasks or activities supported in ICT.

Evaluate educational tasks or classroom practices carried out by students with ICT support.

Enhance collaborative work.

Evaluate the educational practices implemented by the school in relation to ICT.

Promote adequate training of teachers, as an indicator of good practice.

Strengthen reflection on practice.

Administrative management, ability and availability
Providing with an efficient inclusive political, organizational and academic management.

Having the needed resources and infrastructure.

Favoring communication with families.

Promoting inclusive policies and cultures between networks of schools.

The participants in disscusion groups consider that their respective educative centers have committed executive teams, having good technological resourses and the staff have positive attitudes and motivated to use and integrate TIC. However, despite optimal technological conditions gather to initiate processes of innovation and implementation of ICT in support of teaching aids in the classroom, the teacher shows the lack of specific teaching materials to support the teaching.

"My school has exceptional technological equipment and we can not complain about it, but the problem I see is in relation to the use of specific software support for specific educational needs they presented our students. With this, I don't mean we cannot work with. But we have to be very creative" (Teacher \#16).

Content analysis shows that among the factors that most stands out are the stimulate learning or acquiring knowledge using ICT in classroom practices where the vast majority of teachers believe that the use of ICT increases the quality of learning.

"It is clear that the use of ICT is a revolution in the classroom, because it promotes a very positive acquisition of knowledge by students. It's a tool that motivates a lot, and therefore helps in the acquisition of knowledge" (Teacher \#8).

Teacher education appears as a factor to be taken into account. We conclude that there is lack of knowledge on teachers, whether of a technical nature for some and teaching to others, perhaps by generational issues or problems with the training itself, but they are issues that may prevent making good educational practices with ICT support. This aspect is completed, to the possible extent with, another factor that comes to light and is the presence in the two schools of the existence of a ICT coordination team, with the function of advising teachers and revitalize the educational use of technologies.

Teachers are aware that the reflection on practice advances and contributes to achieving best practices with ICT. It is important to share with colleagues the positive experiences where ICT can be used, investigate and reflect on classroom practices in order to improve the performances ICT to learning and collaboratively reflect on the department or faculty on the practice involving the TIC.

A large majority of teachers use assessment practices with ICT support in the school, where they are discussed with the staff of the department.

Teachers report that despite their schools are welcoming communities do not involve parents in the education of students, although at present there are different programs and resources that enable the relationship.

\section{CONCLUSIONS AND DISCUSSION}

Conclussion to highlight:

- There is a positive attitude of teachers in inclusive classrooms to the use of ICT. Teachers are aware that ICT is an essential tool to support attention to student diversity.

- Male teachers have more positive than female teachers towards ICT attitudes. By contrast, no differences between the genders 
were found in the factor related to the role of ICT in professional and educational development.

- Attitude toward ICT is positive in both factors (Support for teacher professional development, and ability and availability). This may be associated with the presence in both schools called ICT coordinating teaching teams. This constitutes a very important aspect, because the direct advice ultimately influence the decisions of teachers whether to use ICT in their educational practices (Lucas, 2008; Sime \& Priestley, 2005).

- Teacher show very positive attitudes towards ICT and attention to diversity thus share with colleagues the positive experiences where ICT is used, investigate and reflect on classroom practices in order to improve performances with these technologies. The implementation of constructivist theories for the design and support of activities or tasks with ICT support contributes to the positive growth of such attitudes.

- Teachers who have greater access to ICTs and therefore a greater chance of interacting with these, have more positive attitudes towards them. It is noteworthy that surveyed teachers with access to these technologies, show a more positive attitude towards them.

-Among the most important factors to provide good educational practice with the support of ICT power they are to stimulate learning and acquiring knowledge; adaptability of the tasks and activities to the heterogeneous characteristics of students; ability to enhance the autonomous individual and cooperative work of students, and its potential for evaluating educational tasks or classroom practices carried out by students.

- Teacher training and optimum technological conditions to initiate processes of innovation and implementation of ICT appear as important factors in developing good educational practices in inclusive classrooms.

-The commitment of the management team with inclusive education and ICT is a key factor in creating enthusiasm and motivation in the faculty.

\section{REFERENCES}

[1] Área, M. 2008. La innovación pedagógica con TIC y el desarrollo de las competencias informacionales y digitales. Investigación en la Escuela, 64, 5-17. http://dialnet.unirioja.es/servlet/articulo?codigo $=2593487$

[2] Área, M. 2010. El proceso de integración y uso pedagógico de las TIC en los centros educativos. Un estudio de casos. Revista Educación, 352, 77-97. http://www.revistaeducacion.mec.es/re352/re352_04.pdf

[3] Área, M. 2010. Un análisis de las actividades didácticas con TIC en aulas de educación secundaria. Pixel Bit. Revista de Medios y Educación, 38, 187-199.

[4] Canales, R., and Marqués, P. 2007. Factores de buenas prácticas educativas con apoyo de las TIC Análisis de su presencia en tres centros educativos. Educar, 39, 115-133.

[5] Zarceño, A. J. and Andreu, P. C. 2015. Las tecnologías, un recurso didáctico que fortalece la autorregulación del aprendizaje en poblaciones excluidas. Perfiles Educativos, 37 (148), 28-35.
[6] Cavas, B. et. al., 2009. A study on science teachers' attitudes toward information and communication technologies in education. The Turkish Online Journal of Educational Technology, Tojet. http://www.tojet.net/articles/822.pdf

[7] Cerrillo, R., Esteban, R.M., and Paredes J. 2014. TIC e Inclusión en aulas de educación secundaria de la Comunidad de Madrid. Análisis de las prácticas docentes en el modelo 1A1. profesorado. Revista de Curriculum y Formación del Profesorado, 18 (3), 81-97.

[8] Fernández-Batanero, J. Ma and Bermejo, B. 2012. Actitudes Docentes Hacia las TIC en Centros de Buenas Prácticas Educativas con Orientación Inclusiva. Enseñanza\&Teaching, 30 (1), 45-61.

[9] Hinojo, F. C., and Fernández Granada, F. 2002. Diseño de escalas de actitudes para la formación del profesorado en tecnología. Comunicar, 19, 120-125.

[10] Krueguer, R. 1991. El grupo de discusión. Guía práctica de la investigación aplicada. Madrid, Pirámide.

[11] Lucas-Martínez, J. 2008. Las condiciones institucionales de formación de los maestros para el uso de las nuevas tecnologías en la escuela primaria. Revista Electrónica de Tecnología Educativa. EDUTEC, 27, 4-6.

http://edutec.rediris.es/Revelec2/revelec27/articulos_n27_PD F/Edutec-E_JLMartinez_n27.pdf.

[12] Mooij, T. 2004. "Optimising ICT effectiveness in instruction and learning: multilevel transformation theory and a pilot project in secondary education". Computers and Education, $42,25-44$.

[13] Sáez López, J. M. 2010. Actitudes de los docentes respecto a las TIC a partir del desarrollo de una práctica reflexiva. Escuela Abierta, 13, 37-54.

[14] Sime, D., and Priestley M. 2005. Student teachers' first reflections on information and communications technology and classroom learning: implications for initial teacher education. Journal of Computer Assisted Learning, 21, 130142. Recuperado el 5 de julio de 2010, de http://www.eric.ed.gov

[15] Sipilä, K. 2010. The impact of laptop provision on teacher attitudes towards ICT. Technology, Pedagogy and Education, 19 (1), 13-16. http://www.eric.ed.gov

[16] Tejedor, F. J. García-Valcárcel A., and Prada, S., 2009. Medida de actitudes del profesorado universitario hacia la integración de las TIC. Comunicar, 33, 115-124.

[17] Verdugo M. A. and Rodríguez, A., 2012. La inclusión educativa en España desde la perspectiva de alumnos con discapacidad intelectual, de familias y de profesionales. Revista de Educación, 358, 450-470.

[18] Fernández Batanero, J. M., and Torres, J. A. 2015. Actitudes docentes y buenas prácticas con TIC del profesorado de Educación Permanente de Adultos en Andalucía. Revista Complutense de Educación, 26, núm. Especial, 33-49.

[19] Luz Colorado, B., and Edel, R. 2012. La usabilidad de TIC en la práctica educativa. RED. Revista de Educación a Distancia, 30, 23-45.

[20] Canales, R., and Marqués, P. 2000. Factores de buenas prácticas educativas con apoyo de las TIC Análisis de su presencia en tres centros educativos. Educar, 39, 115-133. 
[21] Cabero, J. 1991. Actitudes de los profesores hacia los ordenadores y la informática. In M. Cebrian (Dir.). Medios y recursos didácticos. (pp. 85-98). Málaga Secretariado de Publicaciones de la Universidad de Málaga 